\title{
Scaling up innovation: does research and development have a role to play in economic growth? A case of Hungary
}

\author{
Kunofiwa Tsaurai \\ Department of Banking, Risk Management and Finance, \\ University of South Africa, \\ P.O. Box 392, UNISA, \\ 0003, Pretoria, South Africa \\ Email: tsaurk@unisa.ac.za \\ Email: kunofiwa.tsaurai@gmail.com
}

\begin{abstract}
The study investigated the impact of research and development expenditure on economic growth in Hungary using annual time series data ranging between 1996 and 2013. Abundant literature is available which shows that research and development expenditure leads to the improvement in economic growth. However, such studies in the case of Hungary are quite scant. The Johansen and Juselius' (1990) cointegration test noted that there exists a long run relationship between research and development and economic growth in Hungary. Moreover, economic growth was found to have been Granger caused by research and development expenditure in Hungary both in the short and long run, in support of the literature. The study, therefore, urges the Hungarian policy makers to craft and implement action plans that boost research and development expenditure in order to enhance economic growth in Hungary.
\end{abstract}

Keywords: cointegration; economic growth; Hungary; innovation; panel data; research and development.

Reference to this paper should be made as follows: Tsaurai, K. (2017) 'Scaling up innovation: does research and development have a role to play in economic growth? A case of Hungary', Int. J. Education Economics and Development, Vol. 8, No. 1, pp.65-77.

Biographical note: Kunofiwa Tsaurai is a Senior Lecturer in Financial Management. His main areas of research interest include stock market development, foreign direct investment, monetary economics, international banking and finance, investments, credit management and risk management.

\section{Introduction}

Blackburn et al. (2000) noted that research and development result in invention and innovation which improves the efficiency in manufacturing products, increase in productivity levels, international market competitiveness, foreign currency inflows and economic growth. Almost all empirical studies which investigated the impact of research and development concluded that supported Blackburn et al. (2000)'s argument in, as far as, the relationship between research and development and economic growth is 
concerned. Few of them include Bozkurt (2015), Gumus and Celikay (2015), Kokko et al. (2015), Sahin (2015), Barnett (1960) and Ulku (2004).

There is a consensus with regard to the influence of research and development on economic growth in the empirical literature (Yu, 2007; Goschin, 2014; Kwon-Ndung et al., 2014; Blanco et al., 2016). The only difference is that some researchers found out that certain conditions must not only be available but they must have reached a certain minimum level of development for a country to economically benefit from research and development expenditure (Birdsall and Rhee, 1993). The objective of this study is to examine the role of innovation, proxied by research and innovation on the growth of the Hungarian economy.

Despite consensus on the subject matter, no empirical study that the author is aware of has so far been on the influence of research and development on economic growth in Hungary. It is against this background that the author opted to embark on this study in order to make a contribution to literature.

The study used Johansen and Juselius' (1990) cointegration approach alongside Granger causality test in order to empirically examine the role played by research and development on Hungary's economic growth. In comparison to cross country and panel data analysis that have been mostly used by empirical studies on this subject matter, the time series analysis has got an advantage in that it uses data that covers a longer time frame during which most possible economic changes could happen. This paper focus on a single country which has got homogeneous economic characteristics thereby enhancing the reliability of the results for policy making purposes for that particular country.

The rest of the paper is organised into seven sections: Section 2 reviews related literature, whereas Section 3 discusses research and development and economic growth trends in Hungary. Section 4 explains the data and the variables used in the study and Section 5 deals with unit root tests. Section 6 explains the cointegration procedure and results, whereas Section 7 discusses causality framework and findings for the study. Section 8 concludes and recommends.

\section{Literature review}

The neoclassical growth theory is the bedrock upon which the relationship between investment and economic growth is founded. Solow (1962) who founded the neoclassical growth theory observed that higher investment expenditure as a portion of GDP speed up the rate of economic growth. Physical capital stock accumulation and technological progress were identified as the two main external factors that stimulate economic growth, according to the neoclassical growth theory. Romer (1994) upheld the neoclassical growth model's argument by suggesting that positive externalities and spillover effects coming from a knowledge centred economy through increased investment in research and development are the catalysts for economic growth.

On the theoretical front, Aghion and Howitt (1992) argued that research institutions or firms get monopoly rent for whatever innovations that they embark on which are then replaced by future innovations. They further argued that each innovation produces a new intermediate product which can then be used for the manufacturing of the final product in a more efficient manner for the benefit of the economy.

A number of empirical studies supported Aghion and Howitt (1992)'s assertions. For example, Freimane and Balina (2016) examined the relationship between research and 
development and economic growth in the European Union (EU) using the production function-type standard growth model data ranging between 2000 and 2013. They found out that research and development was very instrumental in the promotion of economic growth in the EU member states. Using Johansen cointegration and vector error correction model (VECM) to study the relationship between economic growth and research and development, Bozkurt (2015) observed that research and development and economic growth affected each other in Turkey.

Kokko et al. (2015) employed meta-analysis approach to investigate whether the positive impact of research and development on economic growth in the EU is different from that of other countries. They found out that although research and development had a positive and significant influence on economic growth in the EU, the extent of the research and development's impact on economic growth in the EU was less than in the USA.

Sahin (2015) also examined the nexus between research and development and economic growth in 15 OECD nations using panel data analysis with data ranging from 1990 to 2013. In line with the neoclassical growth theorists (Solow, 1962; Romer, 1994), the study revealed the existence of a unidirectional causality relationship running from research and development investment towards economic growth in the OECD countries. Sahin (2015) argued that nations that invest in research and development tend to able to manufacture superior and technologically advanced products that can compete in global markets. These products generate substantial foreign currency that spearhead the economic growth in the country that manufactures those products.

Barnett (1960:37) argued that investment in research and development improves economic growth, a scenario which in turn enhance economic welfare of the citizens and military security as well. Using panel data analysis with annual data from 1981 to 1997 to explore the relationship between innovation, research and development and economic growth, Ulku (2004) found out that innovation positively impacted the GDP per capita in both OECD and non-OECD countries. However, the same study noted that the research and development stock of innovation's influence on economic growth was significant only in the OECD countries. Using a cross country study, Goel and Ram (1994) examined the impact of investing in research and development on economic growth. Their results also showed that research and development acted as catalyst for economic growth across all the countries that were part of the study.

Gumus and Celikay (2015) employed panel data analysis with data from 1996 to 2010 to explore the link between research and development and economic growth in 52 countries. Their results were twofold:

1 Economic growth was found to have been positively and significantly influenced by research and development investment in all the 52 countries in the long run.

2 The impact of investment in research and development on economic growth was found to be weak in the short run but strong in the long run for developing countries.

Khan (2015) also concluded that research and development was instrumental in the promotion of economic growth in line with majority of empirical work.

Blanco et al. (2016) studied the impact of research and development investment on economic growth in the US using data ranging between 1963 and 2007. They found out that research and development positively and significantly influenced on both output and productivity across the USA. The same study observed that the states characterised by 
higher human capital development were more able to harness research and developmentinduced economic growth benefits. Using panel data analysis with data from 1998 to 2010, Bayarcelik and Tasel (2012) investigated the impact of research and development on economic growth in Turkey. Both research and development expenditure and the number of employees in the research and development projects were found to have had a significant positive impact on economic growth in Turkey in the long and short run.

Griffith (2000) argued that governments should subsidise business's research and development expenditure because of the critical role that it plays in engineering economic growth. According to Nicolaides (2014), research and innovation were important to help save people's lives, improves the companies' competitiveness, enlighten public policy and drove economic growth in South Africa. This was also confirmed by Weng et al. (2012) whose study revealed that research and development investment led to higher levels of technological innovation, the foundation upon which sustainable economic growth was built in Shanghai.

$\mathrm{Yu}$ (2007) examined the role of research and development in China as whole and Chinese regions using the data envelopment analysis framework with data from 532 medium and large-scale firms. Their results confirmed arguments by the majority of empirical research work on the subject matter that research and development investment scale up the levels of innovation and consequently economic growth in China and its regions. However, Goschin (2014) also studied the role played by research and development on economic development in the regions of Romania using panel data analysis with data ranging from 1995 to 2010. In support of the literature, the study observed that research and development had a positive and significant impact on economic development of the Romanian regions. This was also supported by Kwon-Ndung et al. (2014) whose study showed that business research and innovation significantly led to the increase not only in the productivity levels of the firms but also in the improvement in the quality of business strategies formulated for the overall success of the business sector.

Janjua and Samad (2007) investigated the relationship between intellectual property rights and economic growth in Middle East development countries using panel data analysis. They noted that contrary to literature, innovation as proxied by intellectual property rights had a negative influence on economic growth in Middle East developing countries. They argued that this was because the Middle East developing countries were still at a transition stage, a stage of economic transition at which the costs of innovation to the economy are significantly higher as compared to imitation. Using panel data analysis with data ranging between 1990 and 2013, Akcali and Sismanoglu (2015) examined the influence of research and development on economic growth in selected developing and developed countries. They found out that increased research and development enhances the levels of innovation which in turn boost the levels of productivity in the economy and economic growth in general in both developed and developing countries. The same study noted that investment in research and development was paramount to the promotion of international competition and sustainable economic growth in the countries that were part of the study.

Pessoa (2007) studied the link between innovation and economic growth in developed countries. The study observed that the economies of developed countries whose technological frontier was below a certain threshold level did not significantly benefit from research and development investment. A certain minimum level of external competitiveness of the economy was also found to be crucial in terms of enhancing the 
positive influence of research and development investment on economic growth in developed countries that were part of the study. Kristkova (2012) showed that investment in research and development increased the accumulation of knowledge which consequently led to the improvement of productivity levels and consequently boosted economic growth in Czech Republic. The same study, however, noted that increasing research and innovation expenditure on capital goods in the long run was more efficient in the promotion of higher economic growth in Czech Republic in comparison to investment in research and development in other areas.

Birdsall and Rhee (1993) also examined the impact of research and development on economic growth in OECD countries. They noted that research and development positively and significantly influenced economic growth in OECD countries only when personnel and expenditures were used as proxies of investment in research and development. They found out the existence of a unidirectional causality relationship running from economic activity towards research and development expenditure in all OECD countries. Furthermore, their study revealed that research and development could only have a positive influence on economic growth after a country has surpassed a certain minimum level of economic development.

\section{Research and development and economic growth trends}

According to IMF (2015), World Bank (2015) and UNCTAD (2016) statistics, research and development as a share of GDP trends for Hungary versus that of the whole world. For Hungary, research and development expenditure (\% of GDP) surged from $0.633 \%$ in 1996 to $0.792 \%$ in 2000 before further increasing by 0.133 percentage points during the subsequent 5 -year period to end the year 2005 at $0.925 \%$. However, the 5 -year period from 2005 to 2010 saw research and development expenditure (\% of GDP) for Hungary increasing by 0.222 percentage points before further recording a 0.25 percentage points positive growth, from $1.147 \%$ in 2010 to $1.397 \%$ in 2013 (see Figure 1 in Appendix 1).

The entire world saw research and development expenditure (\% of GDP) marginally going up by 0.09 percentage points, from $1.99 \%$ in 1996 to $2.08 \%$ in 2000 before declining by the same margin during the subsequent 5 -year period to end the year 2005 back at $1.99 \%$. Moreover, research and development expenditure (\% of GDP) for the world went up from $1.99 \%$ in 2005 to $2.06 \%$ in 2010 before experiencing a 0.07 percentage points positive increase between the period 2010 to 2013 (from $2.06 \%$ in 2010 to $2.12 \%$ in 2013 ).

Figure 2 in Appendix 1 shows the research and development expenditure (US\$ Billions) and gross domestic product (US\$ Billions) trends for Hungary over a period of 18 years from 1996 to 2013.

Research and development expenditure went up from US\$29.46 billion in 1996 to US $\$ 37.39$ billion in 2000 whilst gross domestic product (GDP) marginally went up by $1.44 \%$ during the same period, from US\$46.54 billion in 1996 to US\$47.21 billion in 2000. The 5-year period between 2000 and 2005 saw research and development expenditure going up massively by $178.54 \%$, from US $\$ 37.39$ billion in 2000 to US $\$ 104.14$ billion in 2005 and GDP also increasing by a huge margin, from US\$47.21 billion in 2000 to US\$112.59 billion in 2005. Moreover, research and development expenditure for Hungary increased by $43.46 \%$, from US $\$ 104.15$ billion in 2005 to US\$149.41 billion in 2010 before further experiencing a $25.93 \%$ positive growth during 
the subsequent 3-year period to end 2013 at US $\$ 188.15$ billion. However, GDP increased by $15.69 \%$ during the 5 -year period from 2005 to 2010 before going up by a further $3.39 \%$, from US $\$ 130.26$ billion in 2010 to US $\$ 134$ billion in 2013 (IMF, 2015; World Bank, 2015; UNCTAD, 2016 statistics). It is clear that both research and development expenditure and GDP for Hungary followed the same pattern during the period between 1996 to 2013.

World Bank (2015) statistics shows that annual growth rate trends of research and development expenditure and GDP for Hungary is shown in Figure 3 under Appendix 1. The former positively grew by 1.10 percentage points, from $12.27 \%$ in 1997 to $13.37 \%$ in 2000 and further went up by 2.87 percentage points during the subsequent 5 -year period to end the year 2005 at $16.24 \%$. The latter however negatively grew by 5.19 percentage points, from $1.38 \%$ in 1997 to a negative $3.81 \%$ in 2000 and then experienced a 12.38 percentage points rebound during the subsequent 5 -year period to close the year 2005 at $8.57 \%$. The research and development expenditure annual growth rate plummeted by 15.31 percentage points between 2005 and 2010 and then rebounded by 15.43 percentage points during the subsequent 3 -year period to close the year 2013 at $16.36 \%$. However, GDP decreased from $8.57 \%$ in 2005 to $0.22 \%$ in 2010 before experiencing a 5.56 percentage points positive growth between 2010 and 2013.

\section{Data and variables description}

Time series annual data for economic growth and research and development for Hungary was used for the purpose of this study. Economic growth was used as a dependent variable and research and development expenditure as an independent variable. GDP annual growth rate was used as a proxy for economic growth whilst research and development expenditure as a share of GDP was used as a measure of innovation consistent with similar empirical studies (Pessoa, 2007; Nicolaides, 2014; Akcali and Sismanoglu, 2015; Bayarcelik and Tasel, 2012).

The Hungary data for the variables used in the study was extracted from World Development Indicators, World Economic Outlook (2015) and UNCTAD (2016) databases, publicly available sources characterised by a very high level of credibility. In line with literature, research and development expenditure is expected to have a positive and significant influence on economic growth for Hungary. Both economic growth and research and development data was auto-correlated at level, which was then dealt away with at first difference.

\section{Unit root tests}

Augmented Dickey Fuller (ADF), Philips-Perron (PP) tests and the Dick-Fuller GLS approaches were used to test for stationarity of both economic growth and research and development expenditure data sets. All the three-unit root testing frameworks were used for comparison purposes, following Tsaurai and Odhiambo (2012). Both data sets were not stationary at level as shown in Table 1 (see Appendix 2).

Table 2 in Appendix 2 shows that both research and development expenditure data sets were stationary at first difference because the intercepts values were lower that the critical values. In other words, both data sets were integrated of order 1, I(1), thus paving way for cointegration tests. 


\section{Cointegration analysis}

The paper employed the Johansen and Juselius' (1990) cointegration framework which makes use of the maximum likelihood estimation approach. The no cointegration is the null hypothesis whereas the alternative hypothesis is that there is a cointegration relationship that exists between the variables being investigated. Akaike Information Criterion (AIC), Final Prediction Error (FPE) and Likelihood Ratio (LR) test were used to estimate the optimum lag length for the Hungary data. The optimum lag length for the data was found to be 2 by the three criterions.

The Johansen and Juselius' (1990) cointegration framework uses the maximum likelihood procedure to examine how many cointegration vectors exist using maximum eigen and trace test statistics.

The maximum eigenvalue $\lambda_{\text {trace }}$ statistic is as follows:

$$
\lambda_{\max }(r, r=1)=-T \ln \left(1-\lambda_{r+1}\right)
$$

The $\lambda_{\max }$ statistic tests the null hypothesis that the number of $r$ cointegrated vectors is $r$ against the alternative of $(r+1)$ cointegrated vectors. The null hypothesis $r=0$ is tested against the alternative that $r=1, r=1$ against the alternative $r=2$ and so on.

The likelihood ratio statistic for the trace test $\lambda_{\text {trace }}$ is given as follows:

$$
\lambda_{\text {trace }}=-T \sum_{i=r+1}^{p} \operatorname{In}\left(1-\lambda_{1}\right)
$$

where $\lambda_{1}$, the largest estimated value of $i$ th characteristic root (eigenvalue) obtained from the estimated II matrix. $r=0,1,2, \ldots p-1 ; T$, the number of observations. The $\lambda_{\text {trace }}$ statistic tests the null hypothesis that the number of distinct characteristic roots is less than or equal to $r$ (where $r$ is 0,1 , or 2 ).

The results in Table 3 (see Appendix 2) shows that both trace and maximum eigen statistics rejects the null hypothesis of $r=0$ against the alternative of $r \geq 1$ at $5 \%$ significance. This provides statistical evidence that at least one cointegrating vector exist in the relationship between economic growth and research and development. In addition, the maximum eigen value statistic reject null hypothesis of $r \leq 1$ against the alternative $r \geq 2$ at $5 \%$ significance level. This suggests that there exist at least two cointegrating vectors in the relationship between the two variables thus paving way for an investigation of which direction the causality runs from and to between economic growth and research and development.

\section{Granger causality tests}

The causality test from research and development and economic growth was performed consistent with Narayan et al. (2008) - see Equation 3.

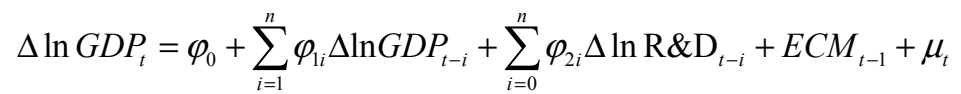


Error correction term (ECM) measured the Granger causality in the long run whilst the coefficients in Eq. (3) test the Granger causality in the short run - see Table 4 in Appendix 2 for results. $\ln R \& D, \log$ of research and development expenditure; $\Delta$, first difference operator; $\mu$ is a white noise error; $\operatorname{lnGDP}, \log$ of gross domestic product; $E C M_{t-1}$, the lagged error-correction term obtained from the long-run equilibrium relationship whereas subscripts $t$ and $t-1$ represents time periods.

In Table (Appendix 2), C(1) is the error correction model (ECM) coefficient which measures the causality between the variables in the long run. $\mathrm{C}(2), \mathrm{C}(3)$ and $\mathrm{C}(4)$ are coefficients for the short run causality. Table 4 in Appendix 2 shows that $C(1)$ is negative and significant, meaning that innovation as measured by research and development expenditure Granger caused economic growth in Hungary during the period under study. The fact that $\mathrm{C}(2)$ coefficient is negative and its corresponding probability is less than $1 \%$ is proof that innovation as proxied by research and development expenditure Granger caused economic growth in the short run as well.

The model in which economic growth and innovation is the dependent and independent variables, respectively, found out that serial correlation and hetero scedasticity were absent. The residual of the model is normally distributed whilst $F$-statistic was found to be significant. The adjusted $R$-squared is $67.02 \%$ (Table 4 in Appendix 2) and is favourable. In summary, these characteristics shows that the model was efficient.

\section{Conclusion and recommendations}

The study investigated the impact of innovation as measured by research and development expenditure on economic growth in Hungary using annual time series data ranging between 1996 and 2013. Abundant literature is available which shows that research and development expenditure leads to the improvement in economic growth. However, such studies in the case of Hungary are quite scant. The Johansen and Juselius' (1990) cointegration test noted that there exists a long run relationship between research and development and economic growth in Hungary. Moreover, economic growth was found to have been Granger caused by research and development expenditure in Hungary both in the short and long run, in support of the literature. The study, therefore, urges the Hungarian policy makers to craft and implement action plans that boost research and development expenditure in order to enhance economic growth in Hungary. Given the availability of data, the study recommends that future studies should investigate the threshold level(s) of research and development which must be reached or exceeded before triggering significant economic growth in Hungary in line with the argument by Birdsall and Rhee (1993). The study can also include other emerging markets and not just Hungary alone.

\section{References}

Aghion, P. and Howitt, P. (1992) 'A model of growth through creative destruction', Econometrica, Vol. 60, No. 2, pp.323-351.

Akcali, B.Y. and Sismanoglu, E. (2015) 'Innovation and the effect of research and development (R\&D) expenditure on growth in some developing and developed countries', Procedia-Social and Behavioural Sciences, Vol. 195, No. July, pp.768-775. 
Barnett, H. (1960) 'Research and development, economic growth and national security', Annals of the American Academy of Political and Social Sciences. Vol. 327, No. 1, pp.36-49.

Bayarcelik, E.B. and Tasel, F. (2012) 'Research and development: source of economic growth', Procedia-Social and Behavioural Sciences, Vol. 58, No. October, pp.744-753.

Birdsall, N. and Rhee, C. (1993) Does research and development $(R \& D)$ contribute to economic growth in developing countries? Policy Research Working Paper Series No. 1221. Washington, DC: World Bank.

Blackburn, K., Hung, V.T.Y. and Pozzolo, A.F. (2000) 'Research, development and human capital accumulation', Journal of Monetary Economics, Vol. 22, No. 2, pp.189-206.

Blanco, L.R., Gu, J. and Prieger, J.E. (2016) 'The impact of research and development on economic growth and productivity in the U.S. states', Southern Economic Journal, Vol. 82, No. 3, pp.914-934.

Bozkurt, C. (2015) 'R\&D expenditures and economic growth relationship in Turkey', International Journal of Economics and Financial Issues, Vol. 5, No. 1, pp.188-198.

Freimane, R. and Balina, S. (2016) 'Research and development expenditures and economic growth in the EU: a panel data analysis', Economics and Business, Vol. 29, No. 1, pp.5-11.

Goel, R.K. and Ram, R. (1994) 'Research and development expenditures and economic growth: a cross country study', Economic Development and Cultural Change, Vol. 42, No. 2, pp.403-411.

Goschin, Z. (2014) 'R\&D as an engine of regional economic growth in Romania', Romanian Journal of Regional Science, Vol. 8, No. 1, pp.24-37.

Griffith, R. (2000) 'How important is business R\&D for economic growth and should the government subsidise it? The Institute of Fiscal Studies', Briefing Note Number. 12, London.

Gumus, E. and Celikay. F. (2015) 'R\&D expenditure and economic growth: new empirical evidence', The Journal of Applied Economic Research, Vol. 9, No. 3, pp.205-217.

Janjua, P.Z. and Samad, G. (2007) 'Intellectual property rights and economic growth: the case of middle income developing countries', The Pakistan Development Review, Vol. 46, No. 4, pp.711-722.

Johansen, S. and Juselius, K. (1990) 'Maximum likelihood estimation and inference on co-integration - with applications to the demand for money', Oxford Bulletin of Economics and Statistics. Vol 52, No. 1, pp.169-210.

Khan, J. (2015) 'The role of research and development in economic growth: a review', Journal of Economics Bibliography, Vol. 2, No. 3, pp.128-133.

Kokko, A., Tingvall, P.G. and Videnord. J. (2015) The growth effects of R\&D spending in the E.U.: a meta-analysis. Economics Discussion Papers, No. 2015-29, Kiel Institute for the World Economy.

Kwon-Ndung, E.H., Kwon-Ndung, L. and Mijap, J. (2014) ,Research and innovation strategies for economic competitiveness and industrial growth: lessons for Nigeria', European Journal of Business and Innovation Research, Vol. 2, No. 6, pp.56-76.

Kristkova, Z. (2012) 'Impact of R\&D investment on economic growth of the Czech Republic - a recursively dynamic CGE approach', Prague Economic Papers, Vol. 2012, No. 4, pp.412-433.

Newey, W.K. and West, K.D. (1987) 'A simple, positive semi-definite, heteroskedasticity and autocorrelation consistent covariance matrix', Econometrica, Vol. 55, No. 3, pp.703-708.

Narayan, P.K., Nielsen, I. and Smyth, R. (2008) 'Panel data, co-integration, causality and Wagner's law: empirical evidence from Chinese provinces', China Economic Review, Vol. 19, No. 2, pp.297-307.

Nicolaides, A. (2014) 'Research and innovation - the drivers of economic development', African Journal of Hospitality, Tourism and Leisure, Vol. 3, No. 2, pp.1-16.

Pessoa, A. (2007) 'Innovation and economic growth: What is the actual importance of R\&D? University of Porto', Research Work in Progress No. 254, pp.1-17. 
Romer, P.M. (1994) 'The origins of endogenous growth', The Journal of Economic Perspectives, Vol. 8, No. 1, pp.3-22.

Sahin, E. (2015) The Relationship between R\&D Expenditures and Economic Growth: Panel Data Analysis 1990-2013, EY International Congress on Economics 11 "Growth, Inequality and Poverty" Ankara, November 5-6, 2015. Paper ID Number 207.

Solow, R.M. (1962) 'A contribution to the theory of economic growth', Quarterly Journal of Economics, Vol. 70, No. 1, pp.65-94.

Tsaurai, K. and Odhiambo, N.M. (2012) 'A dynamic causality test of exports and economic growth in Zimbabwe', International Journal of Economic Policy in Emerging Economies, Vol. 5, No. 3, pp.231-242.

Ulku, H. (2004) R\&D, Innovation and Economic Growth: An Empirical Analysis. IMF Working Paper Number. WP/04/185.

UNCTAD (2016) United Nations Conference on Trade and Development Statistics Report, New York: United Nations.

Weng, L., Song, W. and Sheng, S.B. (2012) 'Empirical research on scientific and technical innovation and economic growth in Shanghai', American Journal of Operations Research, Vol. 2, No. 1, pp.82-90.

World Bank (2015) World Development Indicators, World Bank, Washington, DC.

World Economic Outlook (2015) Adjusting to Lower Commodity Prices. Published by International Monetary Fund, Washington, DC.

Yu, B.H.L.W.X. (2007) 'R\&D and economic growth in China on the basis of data envelopment analysis: evidence from Hebei province', Journal of Technology Management in China, Vol. 2, No. 3, pp.225-236.

\section{Appendix 1}

Figure 1 Research and development (\% of GDP) trends for Hungary and the entire world (see online version for colours)

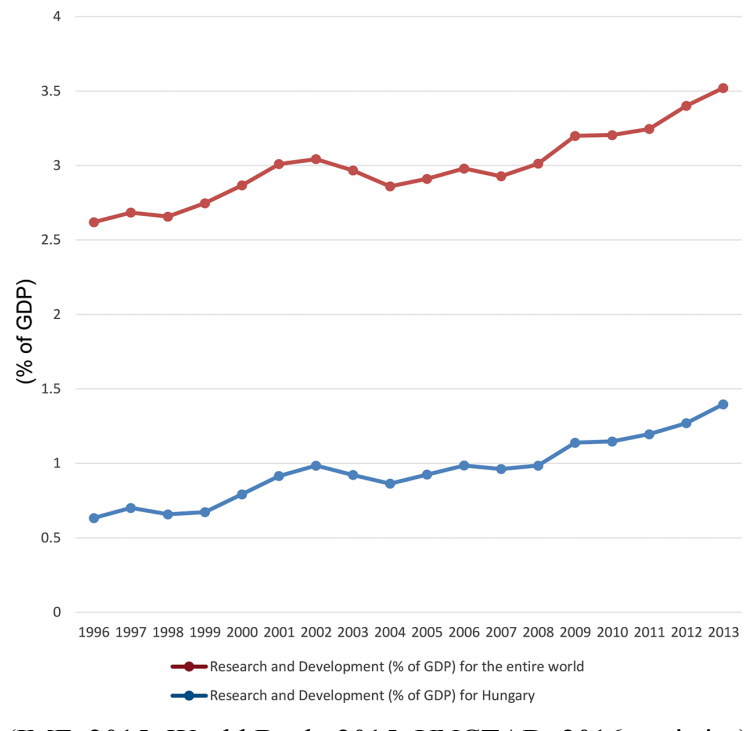

Source: (IMF, 2015; World Bank, 2015; UNCTAD, 2016 statistics) 
Figure 2 Research and development expenditure and economic growth trends for Hungary (1996-2013) (see online version for colours)

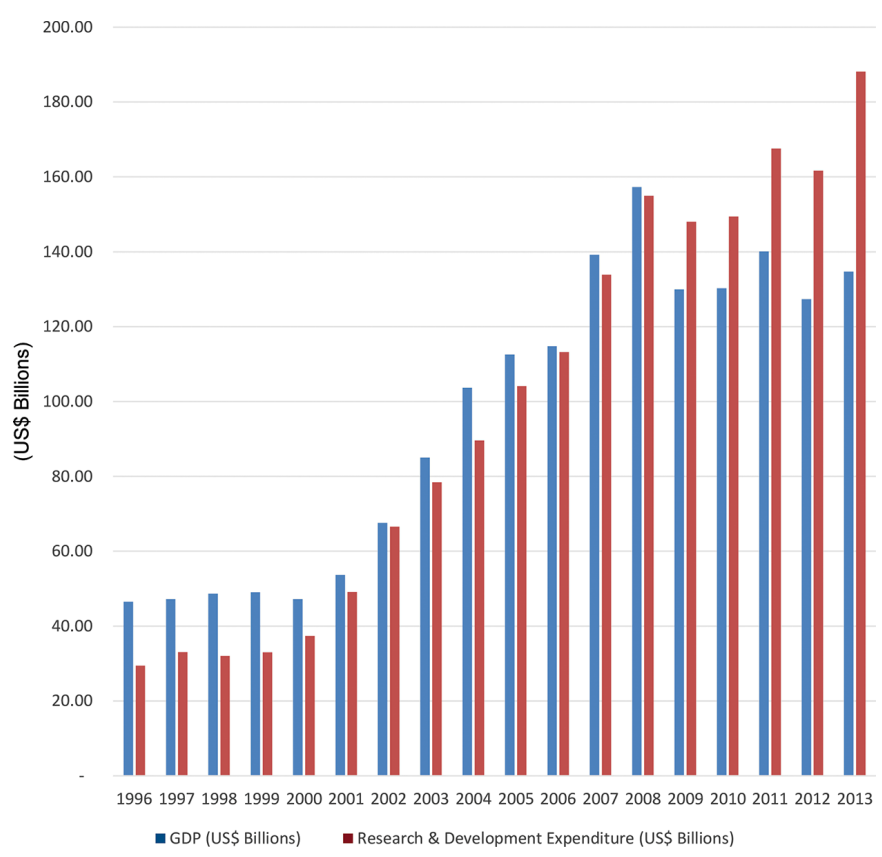

Source: (IMF, 2015; World Bank, 2015; UNCTAD, 2016 statistics)

Figure 3 Research and development expenditure and GDP growth rates for Hungary (1996-2013) (see online version for colours)

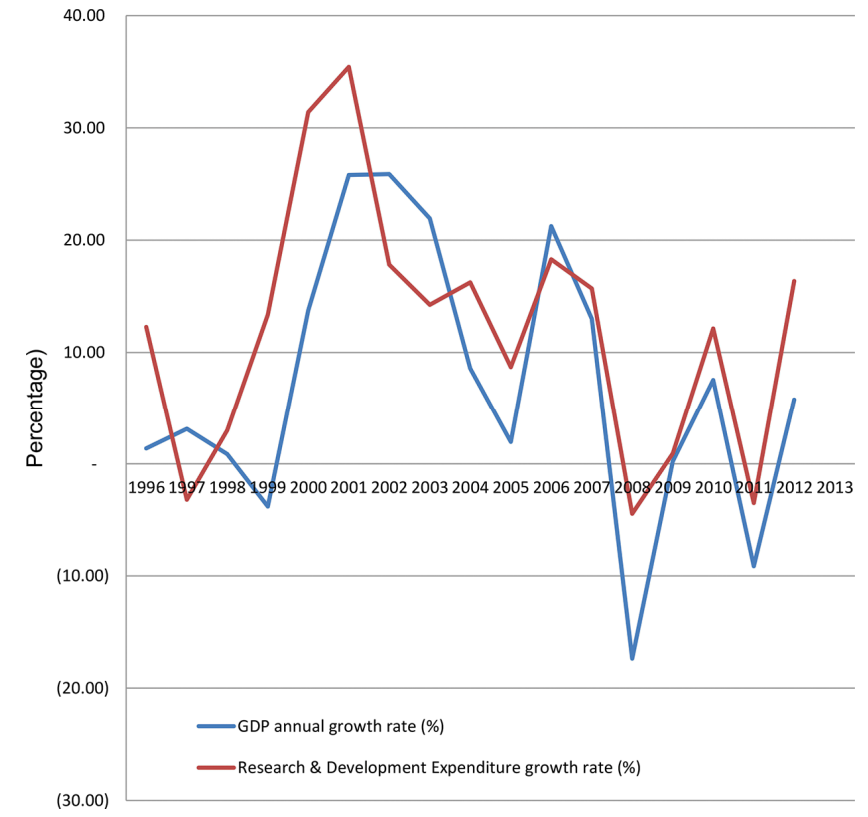

Source: (IMF, 2015; World Bank, 2015; UNCTAD, 2016 statistics) 


\section{Appendix 2}

Table 1 Stationarity tests of variables in levels

\begin{tabular}{lccc}
\hline Variable & \multicolumn{2}{c}{ Test statistic - intercept } & \\
\hline Stationarity tests of variables on levels - augmented & Dickey-Fuller - test & \\
GDP & -2.1145 & $-3.4195^{*}$ & $-2.9502^{* *}$ \\
R\&D & -2.4902 & $-2.0027^{*}$ & $-2.8941^{* *}$ \\
Stationarity tests of variables on levels - Phillips-Perron (PP) test & \\
GDP & -4.0927 & $-3.4189^{*}$ & $-4.39027^{* *}$ \\
R\&D & -2.1294 & $-3.0028^{*}$ & $-2.4287^{* *}$ \\
Stationarity tests of variables on levels - Dickey-Fuller GLS (ERS) test & \\
GDP & -3.2121 & $-2.2318^{*}$ & $-3.7273^{* *}$ \\
R\&D & -0.3382 & $-1.64302^{*}$ & $-1.952473^{* *}$ \\
\hline
\end{tabular}

$*, * * 1 \%$ and $5 \%$ levels of significance, respectively.

The truncation lag for the PP tests is based on Newey and West (1987) bandwidth.

Table 2 Stationarity tests of variables on first difference

\begin{tabular}{lccc}
\hline Variable & \multicolumn{2}{c}{ Test statistic - intercept } & \multicolumn{2}{c}{ Critical values } \\
\hline Stationarity tests of variables on first difference - augmented Dickey-Fuller - test \\
D(GDP) & -11.2174 & $-4.9837^{*}$ & $-3.0021^{* *}$ \\
D(R\&D) & -4.9026 & $-2.9328^{*}$ & $-2.0327^{* *}$ \\
Stationarity tests of variables on first difference - Phillips-Perron (PP) test & \\
D(GDP) & -13.9837 & $-4.2173^{*}$ & $-3.3822^{* *}$ \\
D(R\&D) & -5.9371 & $-3.9803^{*}$ & $-2.6391^{* *}$ \\
Stationarity tests of variables on levels - Dickey-Fuller & GLS (ERS) test \\
D(GDP $)$ & -10.3204 & $-3.9372^{*}$ & $-2.7492^{* *}$ \\
D(R\&D) & -1.9026 & $-1.8382^{*}$ & $-0.2891^{* *}$ \\
\hline
\end{tabular}

$* * * 1 \%$ and $5 \%$ levels of significance, respectively.

The truncation lag for the PP tests is based on Newey and West (1987) bandwidth.

Table 3 Johansen and Juselius cointegration test

\begin{tabular}{lcccccc}
\hline & $H 0$ & $H 1$ & Trace statistic & Critical value & Maximum Eigen & $\begin{array}{c}\text { Critical } \\
\text { value }\end{array}$ \\
\hline GDP $=$ & $r=0$ & $r \geq 1$ & $23.8714^{*}$ & 14.9048 & $28.1739^{*}$ & 21.9372 \\
$\mathrm{f}(\mathrm{R} \& \mathrm{D})$ & & & & & & \\
& $r \leq 1$ & $r \geq 2$ & $19.2527^{*}$ & 11.0727 & 12.0205 & 19.2938 \\
& $r \leq 2$ & $r \geq 3$ & 4.2593 & 7.4792 & 1.9473 & 5.9746 \\
\hline
\end{tabular}

*rejection of null hypothesis at, $5 \%$ significance level 
Table 4 Long run Granger causality results: Dependent variable - GDP

\begin{tabular}{lcccc}
\hline & Coefficient & Std. error & t-Statistic & Probability \\
\hline $\mathrm{C}(1)$ & -0.5902 & 0.2481 & -2.3789 & 0.0126 \\
$\mathrm{C}(2)$ & -0.3826 & 0.1832 & -2.0884 & 0.0027 \\
$\mathrm{C}(3)$ & 7.9372 & 4.9017 & 1.6193 & 0.0428 \\
$\mathrm{C}(4)$ & 1.8329 & 1.8742 & 0.9780 & 0.3782 \\
$R$-squared & & & 0.6925 & \\
Adjusted $R$-squared & & & 0.6702 & \\
$F$-statistic & & & 17.2639 & \\
Prob $(F$-statistic) & & & 0.000013 & \\
\hline
\end{tabular}

